\title{
IN VITRO CYTOTOXIC ACTIVITY OF ISOLATED COMPOUNDS FROM VIBURNUM PUNCTATUM BUCH-HAM EX D. DON
}

\author{
A. RENJITH ALEX ${ }^{*}$, K. ILANGO ${ }^{2}$ \\ 1Department of Pharmaceutical Chemistry, St. John's College of Pharmaceutical Sciences and Research, Kattappana South, Idukki District \\ 685515, Kerala, India, 'Department of Pharmaceutical Chemistry, SRM College of Pharmacy, SRM University, Kattankulathur, Chennai \\ 603203, Tamil Nadu, India \\ Email: renjithalex10@gmail.com
}

Received: 28 Sep 2016, Revised and Accepted: 25 Nov 2016

\begin{abstract}
Objective: The main aim of the study was to screen the isolated compounds of Viburnum Punctatum for its in vitro anticancer activity and its percentage viability against HCT 15 (Human Colon Cancer Cells) Cell lines.

Methods: Pet ether, Chloroform, Methanol and Aqueous extracts was prepared and assayed for the presence of phytochemicals. Two compounds were isolated from the methanol extract of Viburnum Punctatum by column chromatography such as ME1 (Quercetin) and ME2 (Kaemferol-3glycoside) characterised by UV, IR, MS, ${ }^{1} \mathrm{H}$ NMR and ${ }^{13} \mathrm{C}$ NMR. The above isolated compounds were subjected to in vitro anticancer activity on HCT 15 cell lines was evaluated by Micro culture Tetrazolium (MTT) assay.
\end{abstract}

Results: ME1 showed significant cytotoxic activity than the ME2 on HCT 15 cells with a percentage viability of 54.60 and 67.18 in the concentration of $10 \mu \mathrm{g} / \mathrm{ml}$ and $50 \mu \mathrm{g} / \mathrm{ml}$ respectively.

Conclusion: On the basis of obtained results, ME1 and ME2 isolated from a methanolic extract of Viburnum Punctatum represent a new group of cytotoxic against HCT 15 Cell lines.

Keywords: Viburnum punctatum, MTT, Cytotoxic, HCT15

(C) 2016 The Authors. Published by Innovare Academic Sciences Pvt Ltd. This is an open access article under the CC BY license (http://creativecommons.org/licenses/by/4.0/] DOI: http://dx.doi.org/10.22159/ijcpr.2017v9i1.16622

\section{INTRODUCTION}

A diverse range of bioactive molecules are produced by the plant which makes them an enriched source of different varieties of medicines. The ancient scholastic works included in the Atharva veda, charaka and sushruta comprises a rich heritage of knowledge to preventive and curative medicines Natural products plays an important role in drug development programs in the pharmaceutical industry [1] and almost $50 \%$ of all modern drugs are of natural Origin [2], Due to the efficacy and cost-effectiveness of Herbal drugs, it gained much importance in the recent years.

Cytotoxicity is considered primarily as the potential of a compound to induce cell death. Most in vitro cytotoxicity tests measure necrosis; however, an equally important mechanism of cell death is apoptosis, which required different methods for its evaluation [3, 4].

In vitro cytotoxicity tests are useful and necessary to define basal cytotoxicity, for example, the intrinsic ability of a compound to cause cell death as a consequence of damage to basic cellular functions [5]. Cytotoxicity tests are also necessary to define the concentration range for further and more detailed in vitro testing to provide meaningful information on parameters such as genotoxicity, induction of mutations or programmed cell death [6].

The present study on the medicinal plant namely Viburnum punctatum belongs to the family Caprifoliaceae and this plant is small trees, monotypic genus Viburnum, native to India, Indonesia, Bhutan, Cambodia, Nepal, Thailand, Vietnam and China. Asian Viburnum features dainty lymes of creamy white flower at the ends of the branches form early to mid-spring. It has dark green foliage throughout the screen. The red fruits are held in abundance in spectacular clusters in mid-summer, expected to live for $40 \mathrm{y}$ or more $[7,8]$.

The leaves were traditionally used for the treatment for fever, stomach disorder and mentioned to possess antiperiodic effect. The preliminary phytochemical investigation shows the presence of flavonoids, alkaloids, glycosides, phenolic compounds, phytosterols and saponins $[9,10]$. This study was to evaluate the effect of isolated compounds of Viburnum punctatum on anticancer activity in HCT 15 cell line.

\section{MATERIALS AND METHODS}

\section{Cell line used}

HCT 15 Cell lines was maintained in Dulbecco's modified eagles medium and grown to confluency at $37{ }^{\circ} \mathrm{C}$ and $5 \% \mathrm{CO}_{2}$ in a humidified atmosphere in a $\mathrm{CO}_{2}$ incubator. The cells were trypsinized (500 $\mu \mathrm{l}$ of $0.02 \%$ trypsin in PBS/EDTA solution) for two minutes and passaged to T-flask in complete aseptic conditions and incubated [11]. Extracts were added to $80 \%$ confluent cells at a concentration of $10 \mu \mathrm{g} / \mathrm{ml}$ and $50 \mu \mathrm{g} / \mathrm{ml}$ from a stock solution of 100 $\mathrm{mg} / \mathrm{ml}$ and incubated for $24 \mathrm{~h}$. The cytotoxic effect was determined by MTT cell viability assay.

\section{MTT assay}

The ability of the cells to survive a toxic insult has been the basis of most cytotoxicity assays. This assay is based on the assumption that dead cells or their products do not reduce tetrazolium. The assay depends both on the number of cells present and on the mitochondrial activity per cell. The cleavage of MTT to a blue formazan derivative by living cells in clearly a very effective of principle on which the assay is based [12]. The principle involved is the cleavage of tetrazolium salt 3-(4, 5 dimethyl thiazole-2 yl)-2.5diphenyl tetrazolium bromide (MTT) into a blue coloured product (formazan) by mitochondrial enzyme succinate dehydrogenase. The number of cells was found to be proportional to the extent of formazan production by the cells used [13].

\section{Procedure}

The cell culture suspension was washed with 1xPBS and then added with $200 \mu \mathrm{l}$ MTT solution to THE culture (MTT-5 mg/volume 
dissolved in PBS). Then incubate 370C for $3 \mathrm{~h}$. Remove all MTT wash with 1 xPBS and add $300 \mu$ DMSO to each culture. Incubate at room temperature for $30 \mathrm{mts}$ until the cell get lysed, and the colour is obtained. The solution was transferred to centrifuge tubes and centrifuged at top speed for $2 \mathrm{mts}$ to precipitate cell debris. OD was read at $540 \mathrm{~nm}$ using DMSO as blank. The Percentage Viability was calculated using the formula below:

$$
\% \text { Viability }=\frac{\text { Absorbance of Test }}{\text { Absorbance of control }} \times 100
$$

\section{RESULTS AND DISCUSSION}

The in vitro cytotoxicity activity was carried out by MTT assay. From the table 1.1 and 1.2 it showed the percentage viability of HCT 15 cell line is 54-67 which is most suitable to perform cytotoxicity studies. The effect of compound I and II on the growth of HCT15 cells were tested under in vitro conditions using different concentrations $(10 \mu \mathrm{g} / \mathrm{ml}, 50 \mu \mathrm{g} / \mathrm{ml})$ was given in table 1.1 . Compound I $(50 \mu \mathrm{g} / \mathrm{ml})$ exhibited significant cytotoxic activity (67.18\%) compared than Compound II. Compound II exhibited (57.71\%) on HCT 15 cell line.

Plants have been a prime source of highly effective conventional drugs for the treatment of many forms of cancer. In many instances, the actual compound isolated from the plant may not serve as the drug but leads to the development of potential novel agents. The ability to attach agents to carrier molecules directed to specific tumors holds promise for the effective targeting of highly cytotoxic natural products to the tumors while avoiding their toxic side effects on normal healthy tissues.

Table 1.1: In vitro Cytotoxicity of compound I-MTT assay

\begin{tabular}{lll}
\hline Sample concentration $(\boldsymbol{\mu g} / \mathbf{m l})$ & Absorbance (at 234 $\mathbf{~ m})$ & Percentage viability \\
\hline Control & 0.064 & -- \\
10 & 0.035 & 54.60 \\
50 & 0.043 & 67.18 \\
\hline
\end{tabular}

Table 1.2: In vitro Cytotoxicity of compound II-MTT assay

\begin{tabular}{lll}
\hline Sample concentration $(\boldsymbol{\mu g} / \mathbf{m l})$ & Absorbance (at 234 $\mathbf{~ m})$ & Percentage viability \\
\hline Control & 0.071 & -- \\
10 & 0.034 & 47.88 \\
50 & 0.041 & 57.71 \\
\hline
\end{tabular}

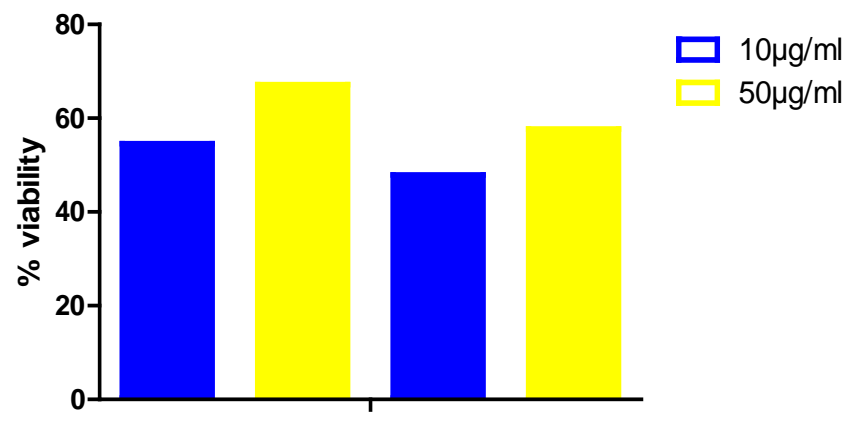

Compound I Compound II

Fig. 1.1: In vitro cytotoxicity of isolated compounds

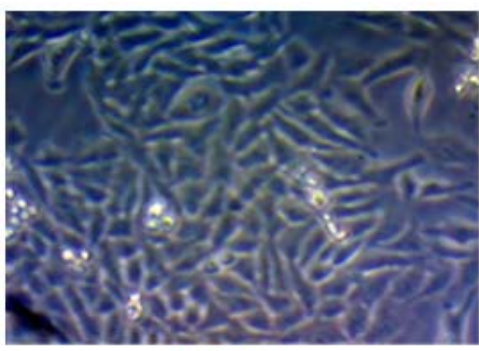

Control

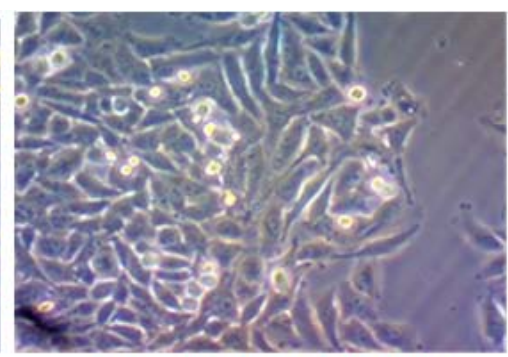

Compound II $(50 \mu \mathrm{g} / \mathrm{ml})$

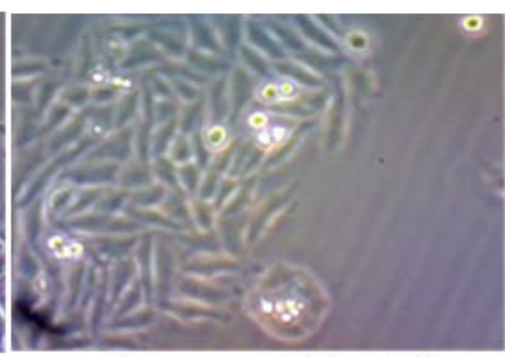

Compound I (50 $\mu \mathrm{g} / \mathrm{ml})$

Fig. 1.2: Cell viability of compound I and compound II on HCT 15 cells

Plants derived from flavonoids have been reported to possess a wide range of biological activities which includes the cytotoxic or anticancer effect. Several reports are available on the anticancer activity of flavonoids isolated from other plants. Based on the results of this study, it can be concluded that the compounds isolated from MEVP like flavonoid have a significant cytotoxic effect on HCT 15 cell line.

\section{CONCLUSION}

It was concluded that compounds from a methanolic extract of Viburnum punctatum contain flavonoid in an enormous amount which exhibits cytotoxic activity. This in vitro assay indicates that both the compounds are a significant cytotoxic effect which might be helpful in other cytotoxic methods. 


\section{CONFLICT OF INTERESTS}

Declared none

\section{REFERENCES}

1. Baker JT, Borris RP, Carte B. Natural product drug discovery and development: New perspective on international collaboration. J Nat Prod 1995;65:1325-57.

2. Stuffiness M, Douros J. Current status of the NCI plant and animal product program. J Nat Prod 1982;45:1-14.

3. Del Regato JA, Spjut HJ. Cancer: Diagnosis treatment and Prognosis. Fifth Edition. CV, Mosby Co; 1997. p. 837.

4. Marcy J, Balunas, Douglas A. Drug discovery from medicinal plants. Life Sci 2005;78:431-41.

5. Adariana B, Rafael M, Gilberto S. Natural products in anticancer therapy. Curr Opin Pharmacol 2001;1:364-9.

6. Gupta Malaya, Upal Kanti Mazumdar. Anti-tumor activity and antioxidant status of Caesalpinia bonduclla against ehrlich asites carcinoma in swiss albino mice. J Pharmacol Sci 2004;94:177-84.

7. Govt of India. "The Wealth of India" Raw Materials, Publications and Information, Directorate (CSIR), New Delhi; 2003. p. 437-46.
8. Gamble JS. "Flora of the Presidency of Madras" Botanical Survey of India, Culcutta; 1995. p. 1-3.

9. Prabhu K, Karar PK, Hemalatha S, Ponnudurai K. Pharmacognostic and preliminary phytochemical investigations on the leaves of Viburnum punctatum Buch-Ham. ex D. Don". J Pharm Sci Res 2009;1:43-50.

10. Renjith Alex A, Ilango K. Phytochemical screening and evaluation of in vitro antioxidant activity of Viburnum punctatum Buch-Ham. Ex D. Don". Am J Phytomed Clin Ther 2013;1:416-23.

11. Vijaya Padma V, Arul Diana Christie S, Dashti N, Wolf bauer G. Induction of apoptosis by ginger in Hep 2 cell line is by reactive oxygen species. Basic Clin Pharmacol 2007;100: 302-7.

12. Berridge M, Herst PM, Tans AS. Tetrazolium dyes as fools in cell biology. Biotehcnol Ann Rev 2005;11:127-52.

13. Shamim Sahranavard, Farzaneh Naghibi, Saeedeh Ghaffari Cytotoxic activity of extracts and pure compounds of Bryonia Aspera. Int J Pharm Pharm Sci 2012;4(Supp 3):541-2.

\section{How to cite this article}

- A Renjith Alex, K Ilango. In vitro cytotoxic activity of isolated compounds from Viburnum punctatum buch-ham EX D. don. Int J Curr Pharm Res 2017;9(1):85-87. 